\title{
Legislation and Governance
}

Journal Issue

Author(s):

Aris, Ben; Bowring, Bill; Grätz, Jonas

Publication date:

2012-11-23

Permanent link:

https://doi.org/10.3929/ethz-a-009911766

Rights / license:

In Copyright - Non-Commercial Use Permitted

Originally published in:

Russian Analytical Digest (RAD) 120 


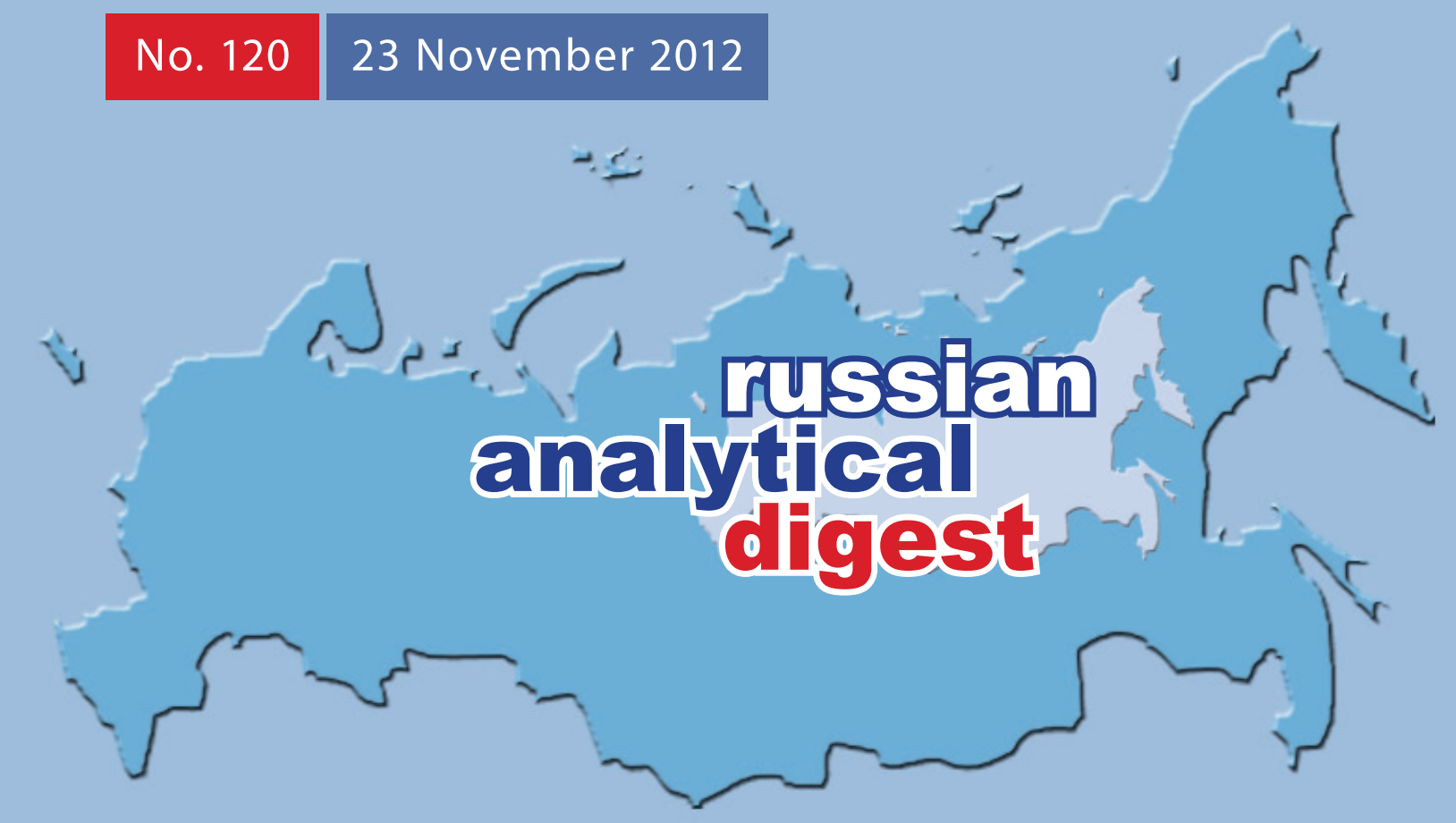

www.css.ethz.ch/rad

www.laender-analysen.de

\section{LEGISLATION AND GOVERNANCE}

ANALYSIS

Russia's Reaction to the Magnitsky Act and Relations With the West

Ben Aris, Moscow

OPINION POLL

Magnitsky, Pussy Riot and Mass Protests

ANALYSIS

Russian Legislation and NGOs in Russia

Bill Bowring, London

OPINION POLL

"Foreign Agents"

ANALYSIS

Control and Internationalization: Rosneft Swallows TNK-BP

By Jonas Grätz, Zurich 


\title{
Russia's Reaction to the Magnitsky Act and Relations With the West
}

\author{
Ben Aris, Moscow
}

\begin{abstract}
The reaction of the US and EU to the death of Sergei Magnitsky by issuing travel bans to 60 Russian officials, and the Magnitsky Act in the US, has become an issue of contention in Russian-Western relations. The Kremlin views the Magnitsky Act as a politically-motivated attempt to interfere in Russian domestic affairs. At the same time, in spite of some mild reforms during the Medvedev Presidency, the Magnitsky case has not had a big impact on either Russian domestic governance or political debate.
\end{abstract}

$\mathrm{T}$ he death of Russian lawyer Sergei Magnitsky on September 16, 2009 in a Moscow pre-trial detention centre was a tragedy and his human rights were almost certainly violated. Magnitsky was a Russian national and a lawyer with the American firm Firestone Duncan. He was representing the UK registered and highly successful fund Hermitage Capital, which had fallen foul of the Kremlin. His death became a lightning rod for tensions between Moscow and Washington and led to the passage of the "Justice for Sergei Magnitsky Act" into the US Congress in 2011, which has driven a wedge between Russia and US foreign relations.

\section{Hermitage Capital}

Run by celebrity fund-manager William Browder, Hermitage Capital was set up early in 1996 and was known for its aggressive shareholder activism. Browder regularly presented embarrassing information to the press as part of its effort to shame the government into improving Russia's corporate governance-particularly in the big state-owned firms such as gas monopolist Gazprom, in which Hermitage was a big investor.

Browder's campaigning led to his visa being pulled in 2006 as a "national threat", but was-according to Business News Europe's information-actually revoked because he embarrassed an oil company close to the Kremlin. The company's offices were raided in June 2007, as were those of Firestone Duncan, and armed police officers confiscated documents and computers. An investigation was opened and three of the fund's holding companies were seized by the state on tax evasion charges. Browder and his lawyers claim that the charges were bogus and actually a scam. The three firms seized by the authorities then successfully claimed $\$ 230 \mathrm{~m}$ in taxes back from the state, which Browder claims ended up in the pockets of state officials.

Browder has since launched a vigorous campaign investing considerable sums in lobbying and publicity to keep the story in the headlights of the press. The campaign has produced much convincing evidence of corruption by tax authorities and other government representatives (most of which is presented in a series of documentaries on YouTube on the "Russian Untouchables" and "Hermitage TV" channels).

In November 2008 Magnitsky was arrested on related tax evasion charges, which Browder claims were instigated as a retaliatory measure by the same officers that were involved in the tax rebate scheme. While in prison he fell ill. It later emerged that Magnitsky had complained of worsening stomach pain for five days prior to his death. Browder and his associates have also found convincing evidence that Magnitsky was beaten while in jail and died after medical aid, to which he was entitled, was denied to him and this lead directly to his death.

\section{Politicised}

The story of Magnitsky is not uncommon in Russia. The new Ombudsman for Business, Boris Titov, was appointed by President Vladimir Putin in July and has already organised the release of seven Russian businessmen who were jailed thanks to false accusations brought by government officials attempting to extract bribes from them. ${ }^{1}$ However, the difference between the Magnitsky case and the more mundane cases has been Hermitage's successful efforts to elevate the profile of the case. At the same time, the Western press has picked up the story, which has come to symbolise many of the problems with Russia's judiciary, penal system and corporate governance in general.

The publicity has not been without effect. The issues that Magnitsky's story threw up fitted with the more liberal and progressive agenda of Dmitri Medvedev, who was elected president in 2008. Surprisingly, Medvedev ordered an investigation into the Magnitsky case in November 2009, which led directly to the sacking of 20 senior prison officials connected to the case in a rare example of the Kremlin listening to public opinion and holding officials accountable for their actions. Medvedev also signed a law forbidding the jailing of individuals who are suspected of tax crimes, which was

1 For more on this see Ben Aris, "Russia's corruption tsar", BusinessNewsEurope (25 October, 2012), http://www.bne.eu/story4121/ Russias_corruption_tsar 
followed by new laws to lighten punishments for corporate crimes in connection with Medvedev's general campaign against corruption.

Following the official investigation, the authorities admitted Magnitsky died due to medical negligence in July 2011. The two doctors have been punished and one of the two doctors is on trial for negligence and manslaughter, all of which is extremely unusual for Russia. However, Browder and Magnitsky's family are far from happy with the extent of the investigation or the actions it has provoked.

\section{Magnitsky List}

What started out as a corporate dispute that went tragically wrong with Magnitsky's death has been elevated to a full-blown international row after the case was taken up first by the European Union and then the US government.

In 2010 MEPs called for a visa ban for 60 Russian officials connected to the case, partly as a result of Hermitage's lobbying. Then in October 2010 US Senator, John McCain, co-sponsored the "Justice for Sergei Magnitsky" bill that became the vehicle for the so-called Magnitsky List that lists the same 60 Russian officials connected to the case and bans them from entry to the US. The government of Canada has passed similar resolutions. The US Senate unanimously passed the Magnitsky Act on June 26 this year, a bill which prohibits foreign human rights violators from entering the US and giving the government the right to freeze their American bank accounts.

The reaction of Russia's foreign ministry has been one of outrage, stating that the resolutions are "an attempt to pressure the investigators and interfere in the internal affairs of another state". Russia has accused the US congress of double standards. The argument is that countries like the US are critical of the weakness of the rule of law in Russia, but that, at the same time, these countries are passing legislation that pre-judge cases and so interfere with the rule of law in Russia.

"We regard such actions as yet another attempt to politicize the issue and put pressure on Russia's justice system," the Russian foreign ministry press service said in a statement in October this year after the European Parliament issued a similar Magnitsky list of a travel ban for selective Russian officials.

During an interview earlier this year, Putin responded to the decisions by the US and EU to impose travel ban lists by stating that "there are people who need an enemy, they are looking for an opponent to fight against", and asking "do you know how many people die while in prison in those countries, which have condemned Russia?". If Washington were to abide by their own princi- ples, argues the Kremlin, then it should leave the case to the Russian judicial system and accept the results of the investigations and ruling connected to the case.

Moreover, the Kremlin sees the Magnitsky list as selectively penalising Russia. The bill was floated as a precedent setting piece of legislation in the same vein as the 1977 Foreign Corrupt Practices Act. In theory the US now has legislation that can be used to punish officials from any country in the world that are implicated (but not necessary convicted) in corruption or murder cases. This list is very long indeed, yet the Kremlin points out the Magnitsky list relates only to Russia and only to the Magnitsky case.

"We call on the European parliament to pay due attention to human rights issues in the EU members, including, for example, blatant violations of Russian-language minority rights in the Baltic states and the glorification of Nazi collaborators in those countries, instead of interfering into domestic affairs of other states," the Russian foreign ministry said in a statement in September to drive home this point. The Russian foreign ministry has been very outspoken on this case and sees it as no more than "Russia-bashing" that has become par for the course in the deteriorating relations between Washington and Moscow.

In September this overt interference in Russian internal affairs, as the Kremlin sees it, led directly to a change in the laws covering non-government organisations (NGOs), whereby any NGO in Russia that is in receipt of foreign funds is required to register as a "foreign" entity. As a result of these laws the United States Agency for International Development (USAID) has closed down its operations and left Russia after nearly 20 years of work. The Foreign Ministry explicitly accused the organisation of having a political agenda and, as a result of the Magnitsky case, has become less tolerant of any organisation that is thought to be representing the political interests of any foreign power operating in Russia.

\section{Non-event in Russia}

The Kremlin's anger is compounded by its failure to appreciate the significance of the Magnitsky case, which is not an issue in the domestic context. This only adds to the anger and belief that the Magnitsky case is a political vehicle engineered by Washington for its own ends, and the result of the vigorous efforts of Browder to extract his pound of flesh in reprisal for his expulsion from Russia.

According to polls the majority of Russians have never even heard of Magnitsky, or if they had heard of him, the case failed to stir them and was quickly forgotten. This June $44 \%$ of respondents in a poll said they 
knew nothing about the Magnitsky case, up from a year ago in August 2011 when 31\% of those polled had never heard the name. Of those that know the case, they blame senior government officials $(12 \%)$ or the investigators $(11 \%)$ for his death, with others blame conditions in pre-trial detention centres $(8 \%)$ or the incompetence of the prison's doctors (8\%). The least likely cause according to respondents was it was an accident $(6 \%)$ (see Figure 1 on p. 5).

These results indicate a general indifference to the case in Russia, which is matched by a similar indifference to the jailing of the members of the punk rock band "Pussy Riot", who performed an anti-establishment protest song in Moscow's main cathedral on February 21, 2012. While the band members were sentenced to two years in jail and became a cause célèbre with the international press - drawing statements of solidarity for the likes of Madonna and Paul McCartney-Russians were largely nonplussed by the band's antics. When group Faith No More played a concert in Moscow earlier this year they brought the remaining members of Pussy Riot on stage to perform, but they were booed off by the young and presumably more liberally minded crowd.

What is missing from most of the international coverage of the story is the domestic context. In Pussy Riot's case some $80 \%$ of Russians describe themselves as Orthodox according to a survey by the state-run pollster VTsIOM in September, and were genuinely shocked by the desecration of the Christ the Savior cathedral, Russia's most important cathedral (see Figure 2 on p. 6).

Likewise, while the advent of a Russian protest movement has been front-page news in the international press since the first demonstrations in December 2011, domestically the movement has lost momentum and failed to resonate with the general population in any city other than Moscow. While there is a hard core of support for the movement in the capital, and the movement has forced the government to react to the popular demands and take popular opinion into account more than they had previously, the overall interest in agitating for change is on a par with the interest in the Magnitsky case: in a recent poll only $2 \%$ of respondents said they would "definitely" join a demonstration if one is organized and another $11 \%$ said they would "probably" join one (see Figure 3 on p. 6).

More generally another poll found that Russian voters value freedom of speech over the right to assemble and are nervous about losing their hard won prosperity should there be a violent or uncontrolled change of regime, such as is happening in North Africa. Add to this traditional Russian fatalism, the impact of the economic crisis on mortality rates and the long tradition of unaccountability of the state to the people, and the
Magnitsky case has much less resonance within Russia, than it does in the West where personal liberty and wellbeing are the paramount principles of society.

\section{Impact on Foreign Relations}

The Magnitsky affair is part of a general deterioration in relations between Russia and the US that is a function of a basic misunderstanding between Washington and Moscow, due to a clash in their respective value systems.

Putin was the first leader to reach out to then-president George W. Bush after the 9/11 attacks and was genuinely interested in becoming a partner of the US. However, he was rebuffed at every turn and relations got steadily worse. Putin called the West to account for this perceived rejection with an important speech in 2007 at the Munich Conference on Security Policy, in which he highlighted the broken promises made by NATO following the fall of the Soviet Union that no troops would be positioned on Russia's border. But with the accession of the Baltic states to NATO this is exactly what has happened. Putin threw down the gauntlet in Munich saying Russia would not stand idly by forever. ${ }^{2}$

"I think it is obvious that NATO expansion does not have any relation with the modernization of the Alliance itself or with ensuring security in Europe. On the contrary, it represents a serious provocation that reduces the level of mutual trust. And we have the right to ask: against whom is this expansion intended? And what happened to the assurances our western partners made after the dissolution of the Warsaw Pact? Where are those declarations today? No one even remembers them," Putin said in the Munich speech.

Medvedev followed up with a speech in the UK following his election as president in 2008 in which he said that Europe was Russia's "natural ally" and called for a new European security architecture-a call that has gone largely ignored. He called for Europe to reach out and reiterated the fact that Russia would not wait forever. Putin closed the circle in his keynote speech at the St Petersburg economic forum this July, outlining that time had run out. He called on the US to step aside and give the role of global coordination of all countries interests to the G20.

The ire the Kremlin feels towards the US is also partly due to the fact that the Kremlin considers that in the last decade real progress has been made towards the goals that the US sets for Russia. "We have seen a civil society start to emerge in Russia and this is due to

2 A full transcript of the speech, courtesy of Munich Conference on Security Policy, can be found in "Putin's Prepared Remarks at 43rd Munich Conference on Security Policy", Washington Post, 12 February 2007, http://www.washingtonpost.com/wp-dyn/con tent/article/2007/02/12/AR2007021200555.html 
a decade of growth. This is healthy and we understand that a mature economy can't become a developed country without a civil society. The state must move towards this so that we have not only a legitimate government, but also one the people trust. Minorities' interests must be respected and accommodated where it is possible," said Putin in St Petersburg.

Most in the West would scoff at these words and point to Magnitsky as proof they are no more than hot air. However, Putin has always said he will go slowly and wants to remain in charge of the process. Putin says that any change-including the changes demanded by the protest movement - must be done "within the framework of the law", thereby ensuring the Kremlin holds all the cards. There has been change, however, the pace of this change is slow and so discounted by the Kremlin's detractors, but the point is that the two sides are arguing from two different perspectives.

While Russia will not abandon the West, it is now actively pursuing ties with Asia- a policy that was manifest within the efforts the Kremlin put into hosting the APEC summit in Vladivostok in September, during which billions of dollars of contracts were signed over cocktails and canapés.

\section{About the Author}

Ben Aris is the editor/publisher of Business New Europe (http://www.bne.eu/), an online news resource and publication covering business, economics, finance and politics in Central, Eastern and Southeast Europe and the former Soviet Union. To subscribe to BNE's newsletters visit: http://www.bne.eu/store/choose.php

\section{OPINION POLL}

\section{Magnitsky, Pussy Riot and Mass Protests}

Figure 1: Who Do You Think is Responsible for the Death of Sergei Magnitsky? (in \% of Total)

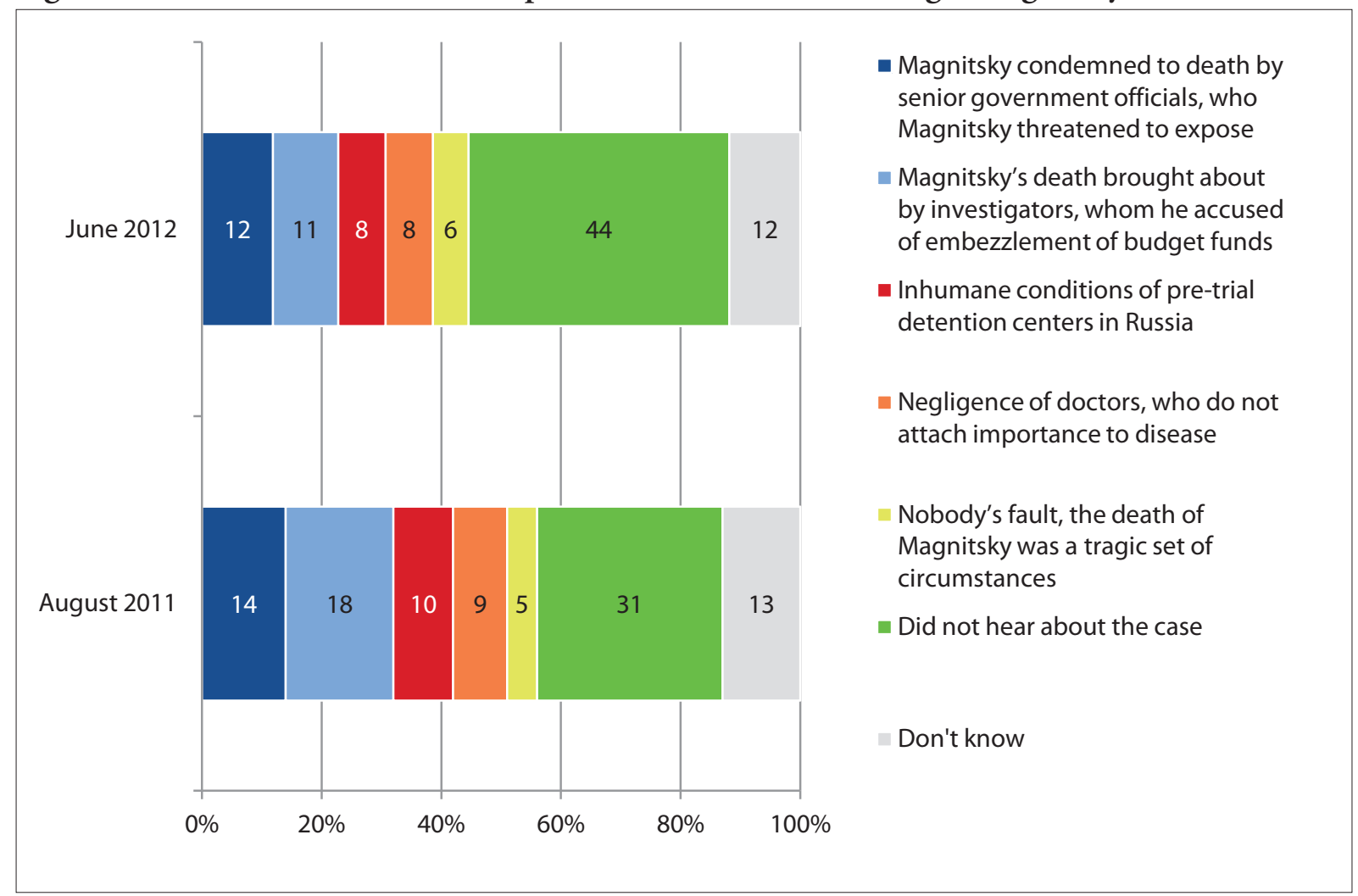


Figure 2: What Feelings Do You Have Towards Pussy Riot? (in \% of Total)

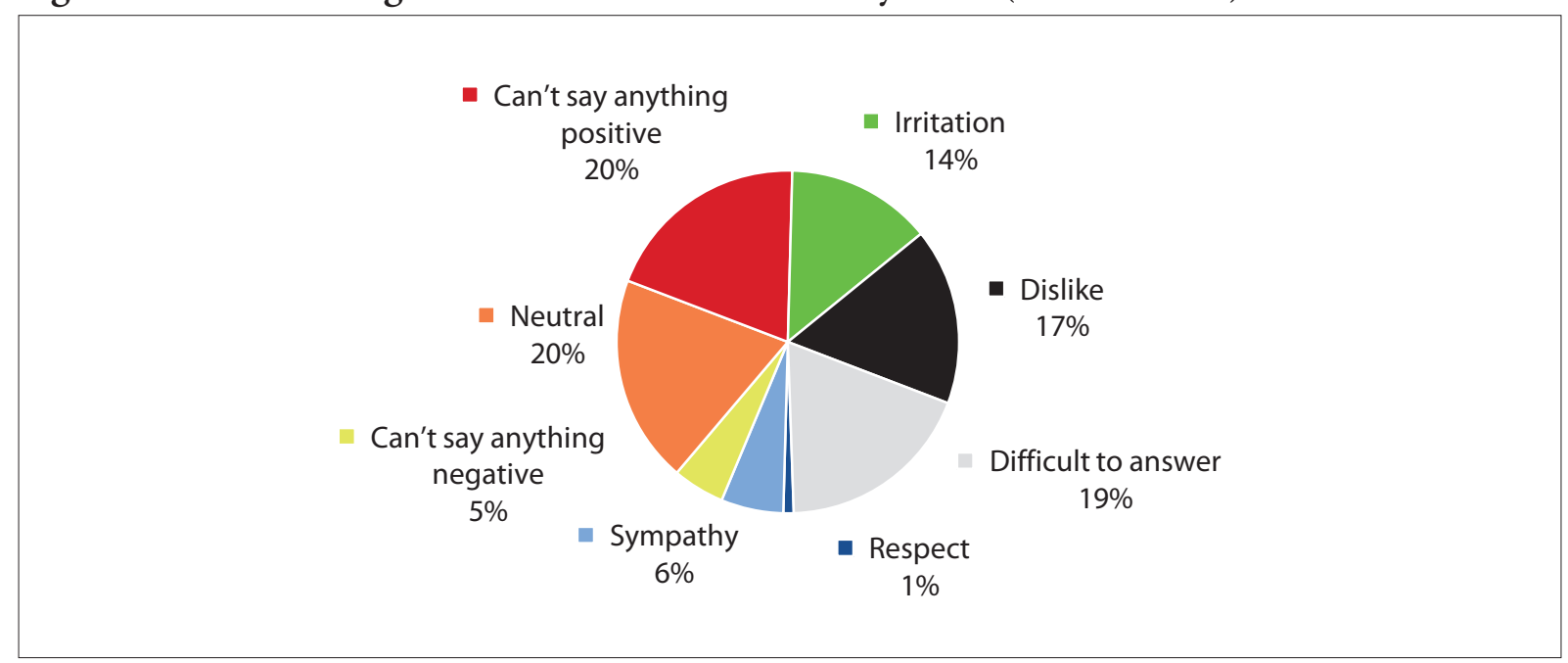

Source: representative poll by Levada Center, 13-18 August 2012,

http://www.levada.ru/17-08-2012/tret-rossiyan-verit-v-chestnyi-sud-nad-pussy-riot

Figure 3: If Mass Protests Against Electoral Violations and Falsification Were to Be Held in Your City or District, Would You Be Willing to Participate? (in \% of Total)

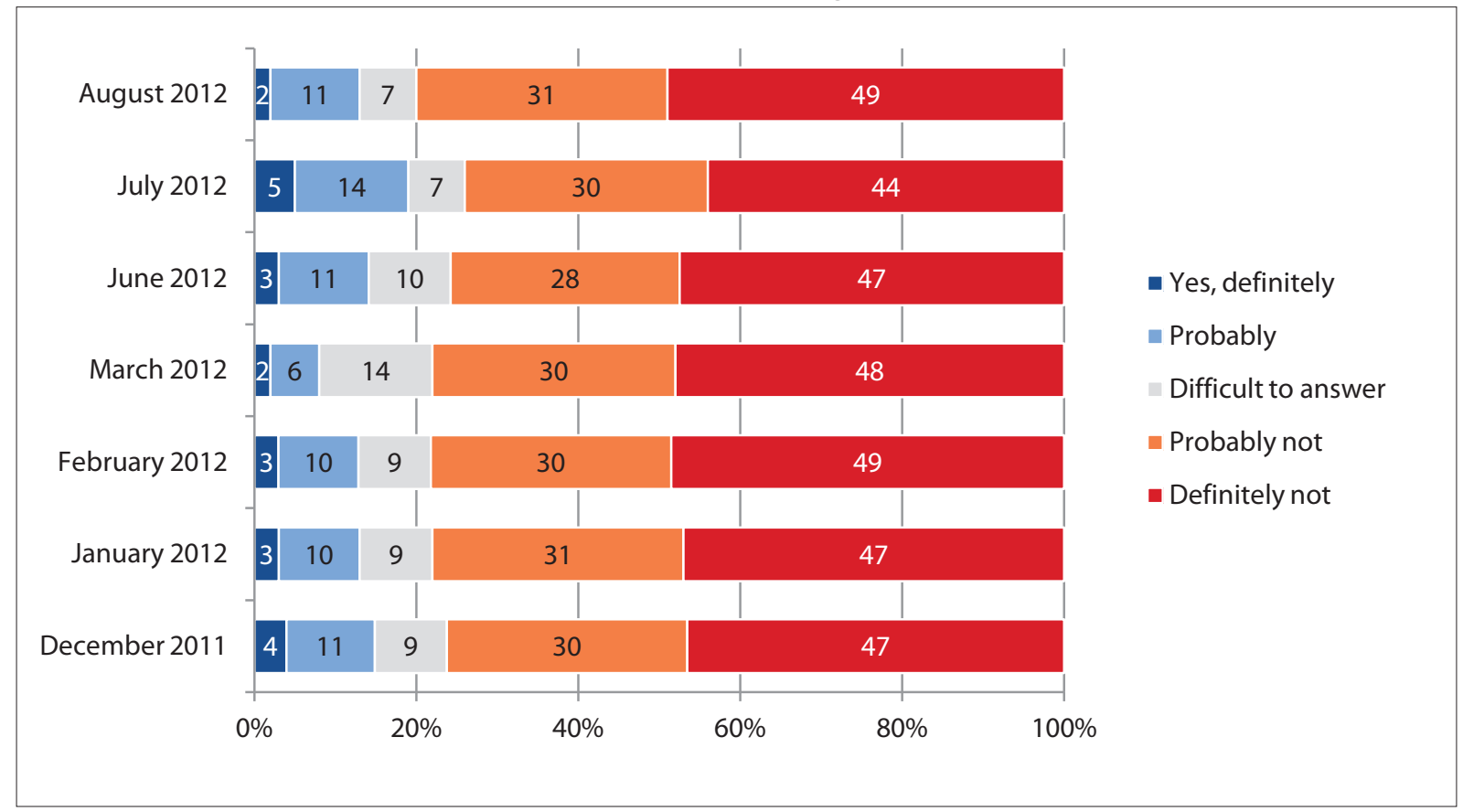

Source: representative polls by Levada Center from December 2011 to 10-13 August 2012,

http://www.levada.ru/28-08-2012/deistviya-vlasti-v-otnoshenii-oppozitsii-i-protestnye-nastroeniya 


\title{
Russian Legislation and NGOs in Russia
}

\author{
Bill Bowring, London
}

\begin{abstract}
In November 2012 a new law on NGOs comes into force, which requires NGOs in Russia with foreign funding and that are engaged in "political activities" to register as "foreign agents". This article traces the development of Russian legislation on NGOs over the last two decades, and assesses the likely impact of this new law. It is argued that at present most NGOs are still trying to clarify the exact meaning of the vague concepts within the new law, but it seems clear that it is aimed at those NGOs deemed to be a political threat to the Putin regime.
\end{abstract}

$\mathrm{T}_{\mathrm{w}}$ wo of the most senior Russian human rights protection non-governmental organisations (NGOs) are now under threat of prosecution and even closure, as the result of a new Federal Law.

These NGOs are the Moscow Helsinki Group, founded in 1976 by a group including the physicists Yuriy Orlov and Andrei Sakharov, and its current Chair, Lyudmila Alekseeva, now aged 85, to monitor the USSR's compliance with the Helsinki Final Act of 1975; and Memorial, founded in January 1989 as a "historical educational society", with Andrei Sakharov as its first Chair. Sakharov's close colleague Sergey Kovalyov, who served a hard labour sentence for anti-Soviet activity-setting up a branch of Amnesty International in the USSRand became Russia's first Human Rights Ombudsman under President Yeltsin, is a member of its Board.

I declare an interest with regard to Memorial. In 2003 I founded, with a grant of $€ 1$ million from the European Commission, the European Human Rights Advocacy Centre (EHRAC) in partnership with Memorial's Human Rights Centre, to assist Russians in taking cases against Russia to the European Court of Human Rights. The project, directed by Professor Philip Leach, is still going strong, and a team of dedicated young lawyers work in Memorial's headquarters in Moscow, with colleagues in Chechnya, Ingushetia and St Petersburg. Memorial has a network all over Russia. In 2005 EHRAC clients won the first six Chechen cases against Russia, and the first environmental case against Russia. There are now several hundred EHRAC cases.

What is this new law? I apologise for giving its full title, but it is relevant. On Wednesday 21 November 2012 the new Federal Law of 20 July 2012, No. 121-FZ "On enacting amendments to certain legislative acts of the Russian Federation regarding the regulation of activities of non-commercial organizations performing the function of foreign agents", published on 23 July 2012 in the Russian Gazette, comes into force. In the vote on this law in the State Duma, 374 deputies voted in favour, 3 against, one abstained, and 72 did not vote at all. The amendments were based on proposals by President Putin.
On Friday 16 November 2012 an opponent of human rights activism in Russia was already licking her lips. She is a leading member of President Putin's United Russia party. "Sabotage of the law on foreign agents by individual NGOs may lead to their suspension" said Olga Batalina, State Duma deputy and Assistant Secretary of the United Russia General Council, according to the United Russia press service. She continued “... a number of non-commercial organizations virtually engaged in politics and financed from aboard, such as the Moscow Helsinki Group or Memorial, have openly announced that they will sabotage this law."

Indeed, these NGOs and many others have declared that they will not register as "foreign agents", and will not pay any fines. Lyudmila Alekseeva told Interfax: "We have said that we are not foreign agents. We cannot brand ourselves that way. Let United Russia prove that Moscow Helsinki Group is a foreign agent. I do not regard myself as a foreign agent. I am not going to tell lies".

There are reckoned to be at least 250,000 NGOs in the Russian Federation, though significant human rights NGOs probably number less than 50. Probably the largest number of NGOs are involved in social welfare and environmental protection. One major problem facing all human rights NGOs and many others is that of finance. The present Russian tax laws strongly discourage private philanthropy - the last of the oligarchs to spend significant sums on charitable activity, Mikhail Khodorkovsky, is still in prison. There are no significant Russian philanthropic trusts. A system of "social contracting" means that social welfare NGOs can compete for the provision of services on behalf of local and central government, and the III Congress of Non-Commercial Organisations, sponsored by the government, recently took place in Moscow, with more than 900 delegates from all of Russia's 83 regions. But human rights protection does not benefit from government money.

It should be no surprise that all the NGOs with which I am familiar are wholly dependent on grants from the West: UK's DFID (until 2003) and Foreign Office, the European Commission, the Open Society Founda- 
tion (George Soros), USAID (until earlier in 2012 when its operations in Russia were wound up), NED, the German Friedrich Ebert and Heinrich Böll Stiftung, Dutch, Swedish and Swiss governments, and various Western charitable foundations. That is, foreign funding.

However, there is a key difference between British (or American) NGOs and those in Russia. In Britain any group of persons can found an NGO. In law this is termed an "unincorporated association"-a group of individuals who enter into an agreement as volunteers to form a body (or organization) to accomplish a purpose. The English courts have defined an unincorporated association as the situation "...where two or more persons are bound together for one or more common purposes by mutual undertakings, each having mutual duties and obligations, in an organization which has rules identifying in whom control of the organization and its funds are vested, and which can be joined or left at will". In Britain, as in most countries, there are no formalities other than the body's own rules or constitution, written or unwritten, and no requirement to register. Only if such a body seeks charitable status, with the tax and other privileges associated with such status, is a complex legal process of formation and regular oversight required.

It is quite different in Russia. Indeed, in the USSR there were no associations of citizens lawfully independent of the state. The advokatura, the Russian bar, had an unusually high degree of independence and self-management, but always subject to ultimate state control.

Moreover, in Russia there is an extraordinary degree of complexity associated with creating an NGO. First of all, there are two forms from which the founders must choose. First, there is the "public association", according to the Federal Law "On public associations" of 19 May 1995 No.82-FZ. Second, there is the "non-commercial organisation", according to the Federal Law "On non-commercial organisations" of 12 January 1996 No.7-FZ. I have asked experts in Russia why there are two laws covering essentially the same subject-matter. The answer is that the two laws were drafted simultaneously in two separate committees of the State Duma, and both were enacted.

Article 7 of the 1995 Law "On public associations" provides that the following may be created under the law:

- public organisation

- public movement

- public foundation

- public institution

- $\quad$ organ of public self-activity

- political party

All such NGOs are subject to compulsory registration with the Ministry of Justice, and to oversight (nadzor) by the prokuratura, the Office of the General Prosecutor. The older NGOs thrived, up until 2006, and thousands more sprang up. However, there was always the possibility of state intervention.

In July 2005 I was in Nizhny Novgorod when the Russian-Chechen Friendship Society and its founder Stas Dmitrievsky, were subjected to a three-fold attack. The Ministry of Justice cancelled the Society's registration. The Ministry of Finance determined that grants received by the Society from the European Commission and the US National Endowment for Democracy (NED) were taxable as pure profit in the hands of the Society, even though all the money had been spent on the projects for which it was donated, and subjected to strict audit. I was present when a huge tax bill including a large fine was presented to Mr Dmitrievsky. Finally, Mr Dmitrievsky was charged and convicted of "incitement to racial hatred" (his activities sought peace and friendship between Russians and Chechens). He was not imprisoned, but the result of his conviction was that under Russian law he could not be a member of an NGO.

However, the law was dramatically tightened in January 2006, when, under President Putin, Russia enacted the Federal Law "On introducing amendments to certain legislative acts of the Russian Federation". These amendments introduced burdensome reporting requirements for NGOs, accompanied by severe penalties for non-compliance; new and similarly burdensome registration procedures for Russian and foreign NGOs operating in Russia; and new broad powers of the registration bodies to audit the activities of NGOs. The new law raised special concerns because it allowed for broad and restrictive interpretation. All human rights NGOs, including Moscow Helsinki Group and Memorial have been subjected to almost daily interference from the authorities, particularly the tax police. And the most minor errors in an application for compulsory renewal of registration can result in long delay or outright refusal.

When Medvedev was elected President in 2008, he sought to mitigate Putin's 2006 amendments, and on 12 January 2009 a further amending law was enacted. However, any relief was short-lived.

So what does the new law entail? It introduces a new concept of the meaning of "foreign agent". It will apply to those NGOs which "take part in political activities" and receive funding from abroad. An NGO will be considered such an organisation if it participates in "organising political acts in order to exert an influence on the taking of decisions by state organisations concerning changes in state policy exercised by them" and influences public opinion "in those aims". Such NGOs will be entered in a special register. Religious organisations, state corporations and companies, and NGOs set 
up by them, are exempt. The following areas of activity are excluded from the concept of "NGOs' political activity": science, culture, art, healthcare, preventative and protective work in health, social support and protection, care of mothers and children, support for people with special needs, information on healthy living, physical culture and sport, protection of flora and fauna, and charitable activity, including involvement in charity work and volunteering.

Pavel Chikov, Director of the Kazan-based NGO $A G O R A$, conducted seminars on the new law in Moscow, Nizhny Novgorod, Novosibirsk, Perm, St Petersburg, Voronezh and the North Caucasus. Representatives from about 300 different NGOs took part, not all of them human rights organisations. On 5 October 2012 he was interviewed by the independent (and human rights oriented) weekly Novaya Gazeta.

The lawyers of $A G O R A$ were, he said, urgently seeking clarification of "flexible" legal terms, like "the formation of public opinion", or "influencing decisions by government agencies". These obscure concepts have become the characteristics of "political" NGOs. If such NGOs receive any foreign funding, they will be obliged to register as foreign agents. AGORA's lawyers are convinced that these characteristics are more or less inherent in all NGOs. Moreover, most NGO leaders are not doing anything about it, even though they are threatened with severe fines and criminal prosecution for not meeting the demands of the law.

Penalties can include suspension of activity, but also fines amounting to millions of roubles for an organisa- tion, and up to 50,000 roubles for its director. According to a newly inserted article of the Criminal Code, "Malicious evasion of the obligations of a foreign agent", this could lead to the criminal prosecution of the NGO's director, and imprisonment for up to four years.

Furthermore, another new Federal Law has further amended the provisions of the Criminal Code on state treason and espionage. There is a new crime: "aiming to pass on information". This includes the gathering of any kind of information threatening the security of Russia, and passing this information to an international organisation. Even an application to the European Court for Human Rights could be punishable as state treason, if the information contained in the application threatens Russia's security.

However, a generalised clamp-down on NGOs is not anticipated. The Putin regime specialises in what Gordon Hahn called "stealth authoritarianism". These extraordinary measures are likely to be directed at NGOs perceived to be a political threat. According to Chikov, a number of NGOs have been told by regional offices of the Ministry of Justice "What are you getting upset about? You don't fall under this law; you don't hold demonstrations, and you're not involved in elections". However, the officials immediately went on to state that this was only their personal opinion, and they themselves were waiting for clarification from Moscow.

Moscow Helsinki Group and Memorial will in any event defy the new law, as will all the best known and most respected human rights NGOs. How far will Putin go in imposing his will, in this new political freeze?

\section{About the Author}

Bill Bowring is a Professor of Law at Birkbeck, University of London; a practising barrister at Field Court Chambers, Gray's Inn; and has represented applicants in the European Court of Human Rights. He has many publications on topics of international law, human rights, and the law of Russia and other Former Soviet Union countries, and frequently acts as an expert for international organisations, and as a court expert in England. 


\section{"Foreign Agents"}

Figure 1: What Is Your Attitude Towards the Tightening Up of the Law on Non-Commercial Organisations and Towards the Stipulation that the Non-Commercial Organisations Receiving Funds From Abroad Have to Register as "Foreign Agents"? (in \% of Total)

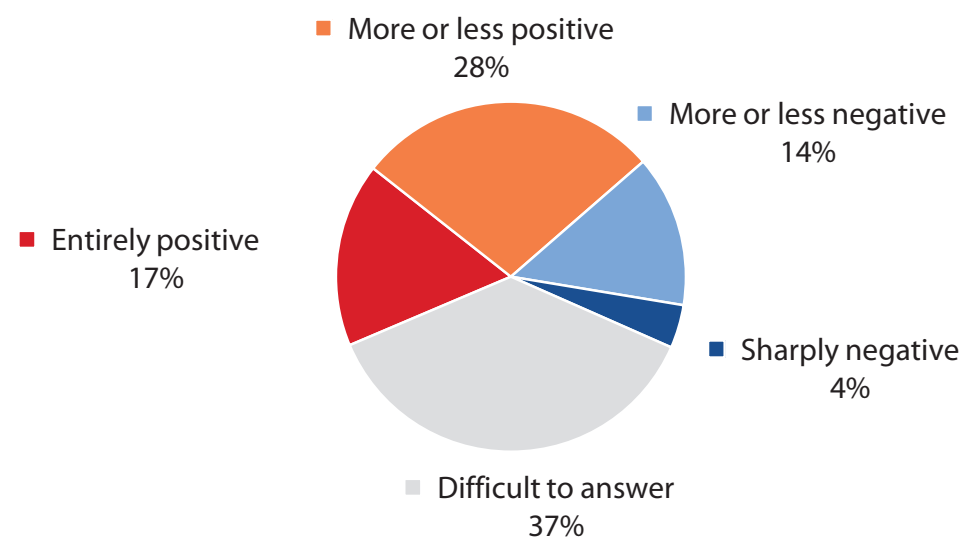

Source: representative poll by Levada Center, 20-23 July 2012,

http://www.levada.ru/01-08-2012/otnoshenie-k-zakonodatelnym-initsiativam-poslednego-vremeni

Figure 2: What Is Your Attitude Towards the Word ...? (in \% of Total)

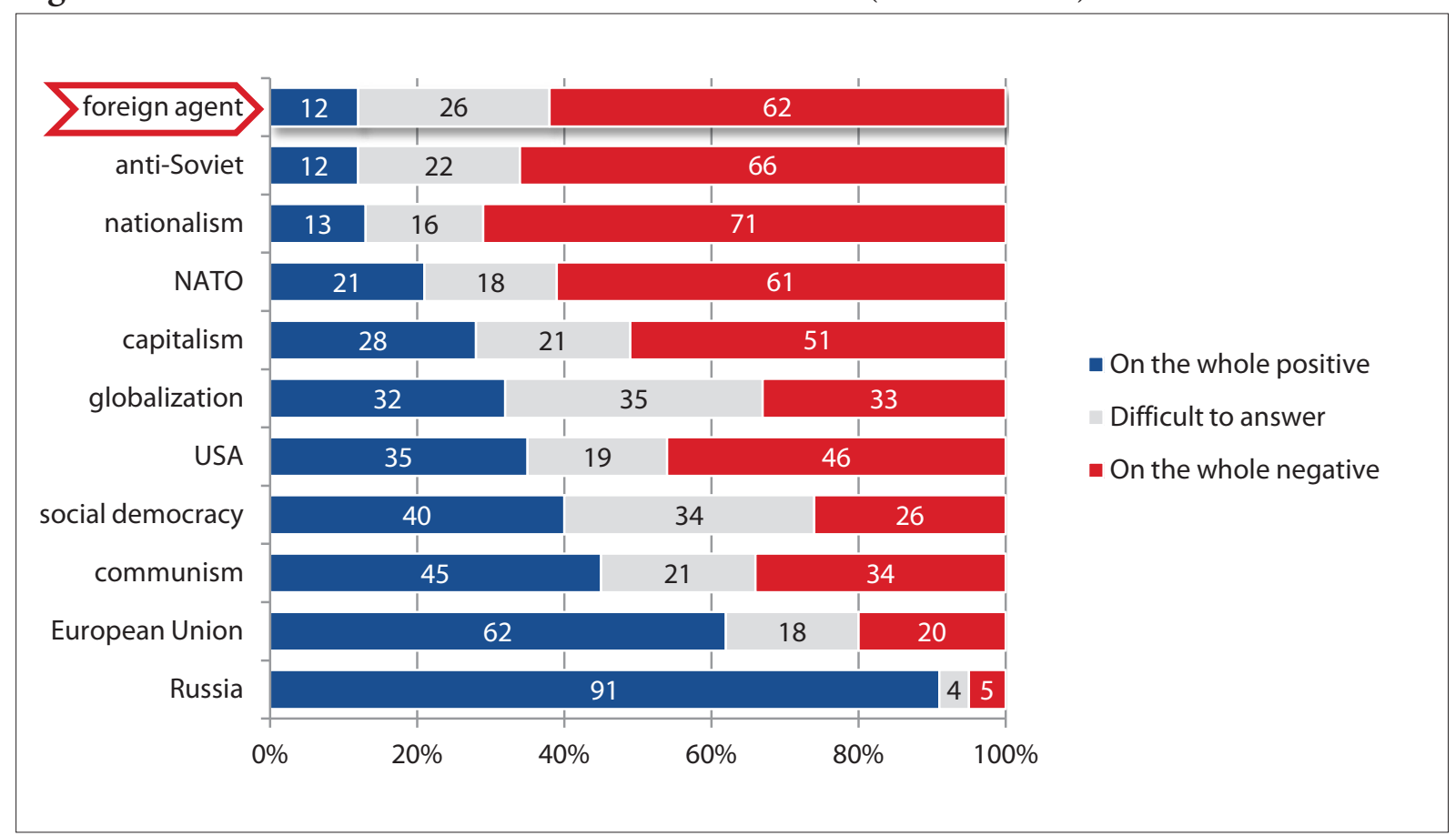

Source: representative poll by Levada Center, 21-24 September 2012,

http://www.levada.ru/22-10-2012/kak-ponimat-slovo-inostrannyi-agent-kommentarii-t-vorozheikino 
Figure 6: What is a "Foreign Agent"? What Does this Term Mean to You? (in \% of Total)

a spy, an agent of the secret service of another state who has been dispatched to [this] country; a secret agent, working "under cover"

a hidden internal enemy working inside Russia for the interests of other countries, the "fifth column"

an official representative of another state or a foreign commercial firm, company or organization who openly represents the interests of their government, firm or company

any public organization, Russian or foreign, which receives financing from abroad for its activities in Russia

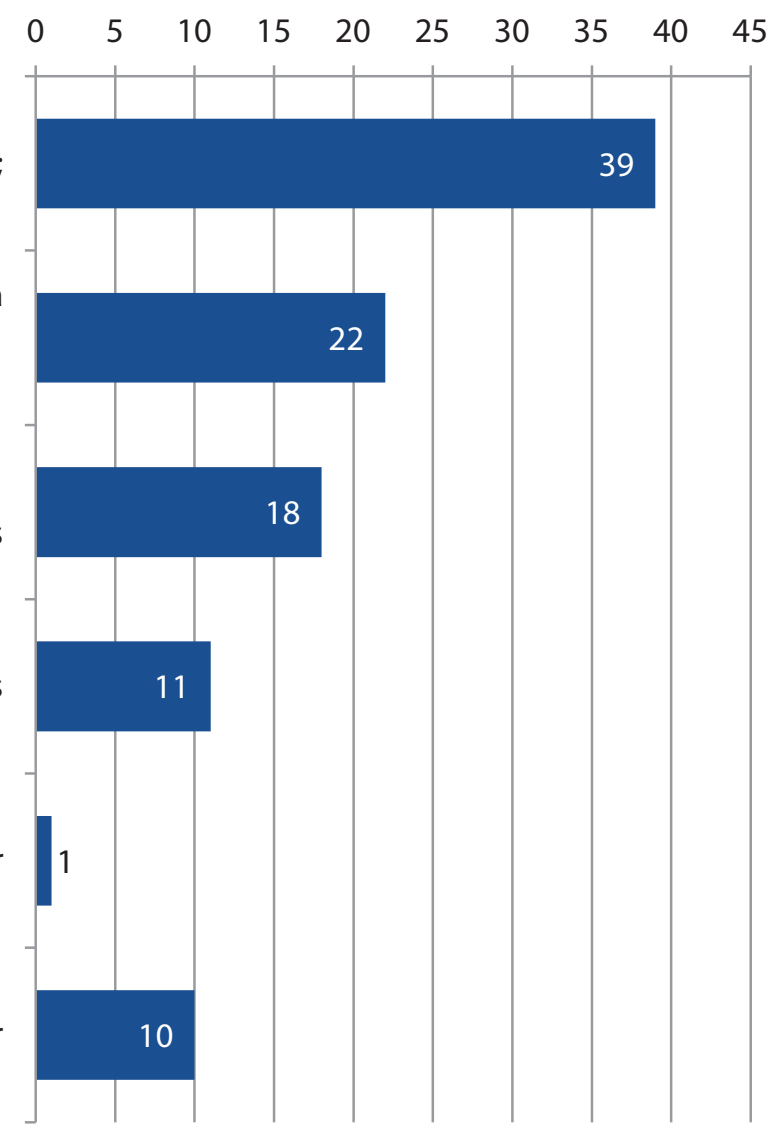

Source: representative poll by Levada Center, 21-24 September 2012,

http://www.levada.ru/22-10-2012/kak-ponimat-slovo-inostrannyi-agent-kommentarii-t-vorozheikino 


\section{Control and Internationalization: Rosneft Swallows TNK-BP}

By Jonas Grätz, Zurich

CCIt's all our money", said Igor Sechin, CEO of Rosneft, during a conference call on Tuesday $24^{\text {th }}$ October 2012. He was talking about the dividends of the jointventure TNK-BP from the first half of 2012. Due to the conflict between the shareholders of BP and AAR, a consortium of Russian "oligarchs", they had not been paid out. The Sunday before this announcement Sechin had come back from London, where he had signed a deal with BP on the takeover of its half of TNK-BP. In exchange, the British oil major would get US-\$17.1 billion plus $12.84 \%$ of Rosneft's shares. Later, BP would buy an additional $5.66 \%$ of Rosneft's shares. Back in Moscow, Sechin inked a deal with AAR to buy their part of the joint venture for US-\$28 billion. Not many details emerged on this agreement, however. The AAR "oligarchs" may yet receive parts of the sum in Rosneft shares, as a concession to "liberal" factions in Moscow. However, the bigger part is likely to be in cash, with a tacit agreement that they will reinvest the major part of it in Russia.

If the takeover of TNK-BP proceeds as planned, which seems likely, it would line up nicely with an overriding political trend pursued by the Putin regime: the displacement of the "oligarchs" of the 1990s from the oil and gas industry and their replacement by members of the "new" regime that have a strong connection to Putin. The trend began with the bankrupting and takeover of oil company YUKOS by Rosneft in 2003/04 and proceeded with the takeover of Roman Abramovich's Sibneft by Gazprom in 2005. Further smaller consolidations followed, such as the squeezing out of international investors from the Sakhalin-II project, or of TNK-BP from the Kovykta project by Gazprom. The actors were always the same: Sechin was the driving force behind the destruction of YUKOS, as he is driving the takeover of TNK-BP today. This continuing recourse to greater control of the regime to alleviate frictions is an indicator of its hardening and a symptom of a lack of elite contestation. This concentration of ever more power in ever fewer hands will not only have repercussions inside Russia, but also on the European oil market.

The deal takes place at a time when signs of systemic tensions in Russia are becoming more apparent. Tensions are not only of a political nature, but also economic. Economic stagnation in the EU and worldwide is having an impact on Gazprom due to lower demand and downward pressure on prices. The premise, on which the export strategy of the conglomerate was basedrestricted supply and rising demand-does not hold anymore. The heavy-handed gas giant is nevertheless pursuing its pipeline mega-projects that do not fit well with the flexibility revolution on the gas market, which has been brought about by liquefied natural gas tankers. Moreover, Gazprom's insistence on oil-price linkage for a supply deal with China obstructed its successful conclusion. Meanwhile, costs are rising due to the expensive mega-projects and the necessity of bringing new fields on stream to replace the declining production of mature fields.

The oil industry does not have problems in marketing, but in production. High taxation and the privileging of the majority state-owned Gazprom and Rosneft led to insufficient investments into new fields and exploration. High taxes put the Kremlin into a position where it can basically choose which fields are being developed by granting tax exemptions.

Against the background of Gazprom's structural problems, Putin apparently chose to bet on Rosneft instead. Despite the suboptimal experiences with Gazprom, he chose to expand politically controlled corporate power instead of strengthening institutions, which could have improved investment conditions in the country. The stronger concentration, meanwhile, will help in leveraging Russian oil reserves towards international players in the oil industry.

After consolidating TNK-BP, Rosneft will be in a dominant position in the Russian oil sector, extracting $40 \%$ of the total. Together with Gazprom Neft, statecontrolled companies will extract half of Russia's oil. Private oil companies, particularly the not so well connected LUKoil, will be left standing. To develop new projects in the Arctic and elsewhere, Rosneft is going to attract foreign capital and know-how, leveraging Russia's resource base. In the course of asset swaps, Sechin and Putin will demand shares in production, refining and marketing assets elsewhere in exchange for the participation of BP and other foreign companies in Russian projects. Rosneft will be able to internationalize quickly as a result. The partnership with BP is excellently suited in this respect.

The course of events has been "civilized" this time, in contrast to the YUKOS takeover. Only one manager of TNK-BP was detained, but "administrative resources" have not been applied more broadly. This may be a sign that the Russian regime is considering the global constraints: the country needs foreign technology and investments and cannot afford negative headlines in the economic press at the moment. But a second, perhaps more 
important driver is the fact that a subtle approach better corresponds to the current needs of Sechin. Whereas he orchestrated the takeover of YUKOS from the background in 2003, he has emerged from the shadows as the leader of Rosneft. Back in 2003, the episode was one of asset redistribution, now it is about their legitimization and the integration of Sechin into the world of global corporate leaders. The YUKOS episode yielded a host of bad press and litigation, which for some time hampered the internationalization of Rosneft. Thus, another raid would have hampered Sechin's ambitions to transform Rosneft into a global energy company by partnering with international majors. The deal with BP shows that those companies are ready to work with statebacked oil companies as the YUKOS episode recedes into the past, regardless of pending legal issues from the YUKOS takeover.

With regard to markets in the EU, it is likely that Rosneft will try to increase its leverage over the trade of crude oil and products. In contrast to Russian natural gas, the market share of oil is growing. Further takeovers or participation in refining assets in Central Eastern Europe and Central Europe are highly likely, as many countries in the region rely on Russian oil supplies. Meanwhile, Russian plans to establish the Urals oil grade as a benchmark for oil pricing would have overarching repercussions for European oil markets. Up to now, oil in Europe was priced against the Brent/BFOE benchmark from the North Sea, which has been produced by many different companies. But its production is in terminal decline. Against this backdrop, Russian investors are currently building a large oil storage terminal in Rotterdam with the aim of establishing a base for Urals trading in the most liquid European oil port. The consolidation of Russian oil production could be useful to garner influence on oil prices.

It is unlikely that the takeover of TNK-BP by Rosneft will bring efficiency gains to the Russian oil industry. Instead, greater regime control and concentration of corporate power will be leveraged to gain greater influence on foreign markets. Also, the regime will have more influence over extra-budgetary flows of oil revenues. Thus, to ease systemic tensions in Russia the regime once again decided to widen its direct control and to expand influence over external markets.

\section{About the Author}

Jonas Grätz is a Researcher at the Center for Security Studies (CSS), ETH Zurich, where he examines European and international energy policy. His recently completed $\mathrm{PhD}$ focussed upon the multinationalization of Russian oil and gas companies.

\section{Additional Reading}

- Poussenkova, Nina: Lord of the Rigs. Rosneft as a Mirror of Russia's Evolution, Baker Institute Policy Report, No. 35 , March 2007, http://www.bakerinstitute.org/programs/energy-forum/publications/energy-studies/docs/NOCs/Papers/NOC_Rosneft_ Nina.pdf.

- Sakwa, Richard: The Quality of Freedom. Khodorkovsky, Putin, and The Yukos Affair, Oxford: Oxford University Press 2009. 
The Russian Analytical Digest is a bi-weekly internet publication jointly produced by the Research Centre for East European Studies [Forschungsstelle Osteuropa] at the University of Bremen (www.forschungsstelle.uni-bremen.de), the Center for Security Studies (CSS) at the Swiss Federal Institute of Technology Zurich (ETH Zurich), the Resource Security Institute, the Institute of History at the University of Zurich (http://www.hist. uzh.ch/) and the Institute for European, Russian and Eurasian Studies at The George Washington University. It is supported by the German Association for East European Studies (DGO). The Digest draws on contributions to the German-language Russland-Analysen (www.laender-analysen. de/russland), the CSS analytical network on Russia and Eurasia (www.css.ethz.ch/rad), and the Russian Regional Report. The Russian Analytical Digest covers political, economic, and social developments in Russia and its regions, and looks at Russia's role in international relations.

To subscribe or unsubscribe to the Russian Analytical Digest, please visit our web page at www.css.ethz.ch/rad

Research Centre for East European Studies at the University of Bremen

Founded in 1982, the Research Centre for East European Studies (Forschungsstelle Osteuropa) at the University of Bremen is dedicated to the interdisciplinary analysis of socialist and post-socialist developments in the countries of Central and Eastern Europe. The major focus is on the role of dissent, opposition and civil society in their historic, political, sociological and cultural dimensions.

With a unique archive on dissident culture under socialism and with an extensive collection of publications on Central and Eastern Europe, the Research Centre regularly hosts visiting scholars from all over the world.

One of the core missions of the institute is the dissemination of academic knowledge to the interested public. This includes regular e-mail newsletters covering current developments in Central and Eastern Europe.

\section{The Center for Security Studies (CSS) at ETH Zurich}

The Center for Security Studies (CSS) at ETH Zurich is a Swiss academic center of competence that specializes in research, teaching, and information services in the fields of international and Swiss security studies. The CSS also acts as a consultant to various political bodies and the general public. The CSS is engaged in research projects with a number of Swiss and international partners. The Center's research focus is on new risks, European and transatlantic security, strategy and doctrine, area studies, state failure and state building, and Swiss foreign and security policy. In its teaching capacity, the CSS contributes to the ETH Zurich-based Bachelor of Arts (BA) in public policy degree course for prospective professional military officers in the Swiss army and the ETH and University of Zurich-based MA program in Comparative and International Studies (MACIS); offers and develops specialized courses and study programs to all ETH Zurich and University of Zurich students; and has the lead in the Executive Masters degree program in Security Policy and Crisis Management (MAS ETH SPCM), which is offered by ETH Zurich. The program is tailored to the needs of experienced senior executives and managers from the private and public sectors, the policy community, and the armed forces.

The CSS runs the International Relations and Security Network (ISN), and in cooperation with partner institutes manages the Crisis and Risk Network (CRN), the Parallel History Project on Cooperative Security (PHP), the Swiss Foreign and Security Policy Network (SSN), and the Russian and Eurasian Security (RES) Network.

The Institute for European, Russian and Eurasian Studies, The Elliott School of International Affairs, The George Washington University The Institute for European, Russian and Eurasian Studies is home to a Master's program in European and Eurasian Studies, faculty members from political science, history, economics, sociology, anthropology, language and literature, and other fields, visiting scholars from around the world, research associates, graduate student fellows, and a rich assortment of brown bag lunches, seminars, public lectures, and conferences.

The Institute of History at the University of Zurich

The University of Zurich, founded in 1833, is one of the leading research universities in Europe and offers the widest range of study courses in Switzerland. With some 24,000 students and 1,900 graduates every year, Zurich is also Switzerland's largest university. Within the Faculty of Arts, the Institute of History consists of currently 17 professors and employs around a 100 researchers, teaching assistants and administrative staff. Research and teaching relate to the period from late antiquity to contemporary history. The Institute offers its 2,600 students a Bachelor's and Master's Degree in general history and various specialized subjects, including a comprehensive Master's Program in Eastern European History. Since 2009, the Institute also offers a structured PhD-program. For further information, visit at http://www.hist.uzh.ch/

\section{Resource Security Institute}

The Resource Security Institute (RSI) is a non-profit organization devoted to improving understanding about global energy security, particularly as it relates to Eurasia. We do this through collaborating on the publication of electronic newsletters, articles, books and public presentations. 